\title{
Ambiances
}

anbiances Environnement sensible, architecture et espace urbain Varia | 2014

\section{Performing Everyday Practices}

Atmosphere and Aesthetic Education

Les pratiques quotidiennes en acte-Ambiances et éducation esthétique

\section{Carsten Friberg}

\section{(2) OpenEdition \\ 1 Journals}

Electronic version

URL: http://journals.openedition.org/ambiances/464

DOI: 10.4000/ambiances.464

ISSN: 2266-839X

\section{Publisher:}

Direction Générale des Patrimoines - DAPA - MCC, UMR 1563 - Ambiances Architectures Urbanités $(\mathrm{AAU})$

\section{Electronic reference}

Carsten Friberg, «Performing Everyday Practices », Ambiances [Online], Varia, Online since 14

November 2014, connection on 19 April 2019. URL : http://journals.openedition.org/ambiances/464 ; DOI : 10.4000/ambiances.464

This text was automatically generated on 19 April 2019

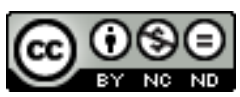

Ambiances is licensed under a Creative Commons Attribution-NonCommercial-NoDerivatives 4.0 International License. 


\title{
Performing Everyday Practices
}

\author{
Atmosphere and Aesthetic Education \\ Les pratiques quotidiennes en acte-Ambiances et éducation esthétique
}

\author{
Carsten Friberg
}

\section{Introduction}

1 I will argue for an intersection between atmosphere and aesthetic education as a fruitful junction between, on the one hand, atmosphere concerning an awareness of sensorial and bodily aspects of our everyday practices, and on the other, aesthetic education understood as our training of those sensorial and bodily skills for dealing with everyday situations. For the concept of atmosphere I follow Gernot Böhme in understanding it as an aspect of perception (Böhme, 2001) and furthermore with emphasis on the presence of a perceived object (p. 35ff.). This view recognises how we, along with grasping what something is in perception, become also sensorially and bodily affected by what we perceive. The sensorial organisation of our environment is not only a result of our intentions of forming our environment; we are ourselves in return also formed by the environment.

2 This forming of our senses and body is the foundation for our daily practices, which is, to a very large degree, based on the embodied knowledge that constitutes the immediate acts that make up most of our everyday practices. Immediate acts are based on experiences that are thus not arbitrary but founded on reasons based on an appropriated knowledge. Reason does not mean an explicit reasoning expressed in propositions, and following formal rules of inference, but what we acknowledge as reasonableness related to what makes sense in the specific situation (Toulmin, 2003).

3 Such forming of our sensorial and bodily ability to practice daily situations is an education of our social competences, or simply the formation of our character in general - our Bildung. Bildung is, of course, about the formation of our spirit, but it also implies an attention towards the sensorial and bodily element in our education, which is the reason for talking about aesthetic education. One could here think of how Friedrich Schiller in 
his letters on aesthetic education advocates for the uniting of the sensuous and the formal drive, the formal drive being related to reason, which can relate to a long debate on how we are influenced by cultural products beginning with Plato's criticism in his Republic (376e-403c) of the use of myths for educating the citizens of Athens. The idea of education concerns a concrete human being with a body, and how the body needs training to form the foundation for a socially capable, i.e. moral, being. Plato and Aristotle could emphasise the importance of bodily exercises for the education of the citizen (Plato, Laws II; Aristotle, Politics VIII), and in early modern age we find it demonstrated in Lord Chesterfield's letters to his son:

I hope you do not neglect your exercises of riding, fencing, and dancing, but particularly the latter: for they all concur to dégourdir [...] to dance well, is absolutely necessary in order to sit, stand, and walk well (Chesterfield, 2008, p. 230, emphasis in original - dégourdir means to remove stiffness).

In between we find a wide range of different interests in sensorial and bodily training within the Western culture: a Christian discussion on whether our inclination to sin, concupiscence, is related to the flesh or to the weakness or corruption of our nature (Gross, 1960, p. 319ff.), in either case calling for a training to resist bodily weakness; an interest in our appearance for the sake of health and social order in cosmetics (Di Stefano, 2012, p. 50ff.); or an interest in the appropriate way of expressing our thoughts in speech, the decorum or aptum of the rhetoric (Quintilian, Institutio Oratoria 11), to name some examples.

The interest in sensorial and bodily training points to the importance of combining this education of our bodily presence with a focus on the cognitive elements of the senses which was exactly what was introduced as aesthetics by A.G. Baumgarten. His intention was to give a philosophical foundation for sensorial cognition (Scheer, 1997, p. 53ff.; Cassirer, 1932, 1998, p. 453ff.; Gross, 2002). In some more recent works within aesthetics emphasis has again been put on the sensorial and bodily elements of our cognition (Böhme, 1995, 2001; Perniola, 1997, p. 153ff.; zur Lippe, 2000; Shusterman, 2000, 2012; Berleant, 2010). The concept of atmosphere is of particular interest in offering an understanding of how everyday objects and the organisation of our environment, such as in architecture and urban planning, participate in forming our perception. It is this forming I call aesthetic education as it takes part in forming us as social beings. Here lies the junction between atmosphere and aesthetic education, where the awareness of sensorial aspects of our everyday practices offered with the concept of atmosphere is not only an awareness of the sensorial elements in our environment but an awareness of our awareness, i.e. an awareness not only of the sensorial elements as such but of how they form our perception thus also form our understanding of the environment we are in.

\section{Atmosphere and the Environmental Effects}

6 When using our social skills in different situations we are, to a large degree, not aware of them; we simply act. It is when the situation requires our attention that we become aware of them. We may experience this when going to a party, at the theatre, a social gathering and other similar events that differ from our everyday practices, and where we become more aware of our presence - about how we present ourselves through our dress, what we should say to other people, as well as how we should say it, and so on. These situations 
require, for most of us, that we pay attention to how our social skills are exercised in order to not attract unintended attention.

7 These examples concern our knowledge of how to perform our presence in specific situations where the environment plays a significant role. It is obvious when mentioning going to the theatre or a concert, which are situations that form exceptions to our everyday life, but any ordinary place also exercises an influence on us, inviting or asking for a specific behaviour. For one who never visits restaurants or uses sport facilities, the first visit to these places is a confrontation of one's sensorial and bodily background with the behaviour of people and the organisation of the physical environment.

The materiality of our world embodies specific interpretations and ideologies. This is of interest for many studies, most notably studies in material culture. I wish to stay within a philosophical interest in the importance of materiality regarding how we perceive and think about our environment, and especially how this environment forms our perception. The philosophical tradition is usually not seen as the first choice when it comes to such an interest, but the references above to Plato and Aristotle were meant as hints as to how materiality and our bodies are not ignored or repressed in philosophy but something to take into consideration when characterising a moral being. One should not confuse the interest in the process of thinking seen independent of matter, body and the senses with ignoring or rejecting the body and the senses. To live only a life of contemplation, no matter how much praised it is, is to live a life for gods and not for men as Aristotle says in his Nicomachean Ethics (1177 b 25).

9 It is true that materiality and body have no place in ideas of pure theory of classical metaphysics as well as in modern scientific theories; but the philosophical tradition has taught us to distinguish between theoretical and practical knowledge; and contemporary philosophy has questioned the idea of pure thinking or pure reason. To be occupied with theory is, to use a characterisation of G.W.F. Hegel, to be out of the body to gain insight of the material world we wish to understand. When the mind seeks to understand how understanding comes about, it has also to be out of itself, i.e. being confronted with its own products to find itself in them (Hegel, 1970, 1999, p. 50ff.; cf. Böhme, 2003, p. 79).

Such a confrontation does not only concern the arts, as in the reference to Hegel above, but is a fundamental model for human understanding including all products of human activites including the very concrete, such as Dominique Laporte illustrates with the Edicts that in 1539 were given to the citizens of Paris regarding trash (Laporte, 1978, 1993). One can see this as simple rules of organising the city but any rule will also organise our behaviour and perception of something.

To touch, even lightly, on the relationship of a subject to his shit, is to modify not only that subject's relationship to the totality of his body, but his very relationship to the world and to those representations that he constructs of his situation in society (Laporte, 1993, p. 29).

11 The material organisation of our environment displays how we understand specific formations of our relation to the world through our acts. They are, as said above, immediate and embodied to make us act without paying much attention to the significance of what we do, but in moments of reflection they become objects of interest for understanding our implicit word-interpretation.

12 Another example, similar to the one of Laporte, is how the development and use of bathrooms is not only a story of hygiene and comfort; it is also a story about the privatisation of personal matters and of a social differentiation. 
[T] he bathroom modified the relationship of human beings to their own bodies and to all their physiological functions: the elimination of wastes became private activities. [...] Beyond any hygienic preoccupations, an increasingly emphatic intolerance for unpleasant odors - or those that were deemed unpleasant to the sensibility - led to the enclosing of spaces that had traditionally been left open. Obviously this process also applied to other living areas besides the bathrooms (Maldonado, 2000, p. 253).

Such examples make clear how central a role architecture, urban planning and design play in exercising a direct influence on us by embodying specific social interests and ideologies, and making us reproduce the appropriate behaviour. Through the organisation of physical space architecture participates in forming our sensorial and bodily relation to the world by inviting, or asking, us to act in specific ways. We participate in, and adapt ideologies through, the material organisation of our world, and often we will not recognise these ideologies because we are fully absorbed by them in our daily routines.

It is in this context the concept of atmosphere should be seen as enabling a perspective on how our perception of places and situations is affected by our surroundings in all aspects of our everyday life. Atmosphere is not only serving an interest in making us aware of a certain tuning or colouring of places relating to an emotional state influencing how we perceive a place. This is just one important aspect of atmosphere: adding a multisensorial awareness to perspectives that often become too narrowly oriented towards function, vision and perhaps to elements of an event culture of experience economy. Atmosphere also implies an awareness of the forming of our understanding of places and our relation to them being about perception itself (Böhme, 1995, p. 47ff.; Böhme, 2001; Thibaud, 2003; Griffero, 2010, p. 11ff.).

\section{Atmosphere as an Aspect of Perception}

5 In the act of perception we aim at understanding something. When perceiving an object we perceive it as something - the locus classicus in philosophy is found in Aristotle, when he states that the white we see, we see as a man (De Anima, 425 a 25). We distinguish between what we consider to be of relevance and what is irrelevant for determining the object. Irrelevant does not imply without any interest, only that it is secondary to our primary concern for understanding. The bottle in front of me, to take a simple example, is blue, but it is primarily an object identified as a bottle before it is seen as something blue - the appropriate answer to what it is, is " a bottle ", not « it is blue ». The sensorial and bodily aspects of our perception are to a large degree considered secondary to the intellectual desire of determining something; they are accidental to use a language going back to Aristotle (Seel, 2000, p. 47ff.).

To judge blue secondary to the bottle is a matter of perspective in the situation, perhaps a matter of taste. And taste matters. The critique of the sensorial, from Plato and onwards, was a critique of how we are influenced by the sensorial in our judgements, which is inappropriate and false in the scientific perspective, and potentially misleading and dangerous in the life of politics. The point is not to reject the sensorial elements; the point is to learn how to handle them.

The example above of how bodily odours can become socially stigmatising, demonstrates how we not only respond to a sense impression; we also respond to a significance we add 
to it. How we understand another person, and objects as well, may be thought to depend on how we read or decode the different signs we encounter. The intention of introducing the concept of atmosphere is exactly to redirect attention from reading signs to our response to sensorial elements present in what we perceive (Böhme, 2001, p. 145ff. and 159ff.). The point is to emphasise that when we perceive something we perceive not only what it is, but we perceive it to be present, and this presence affects us bodily. Perceiving is more than understanding what something is (p. 73ff.), and the characteristics of atmosphere offered by Gernot Böhme bring awareness to perception as primarily the presence of something and not the perception of something specific (Böhme, 1993, p. 125).

Böhme's discussion of perception belongs to a phenomenological tradition and bears similarities to others such as Martin Heidegger and Maurice Merleau-Ponty. An example from the latter can be illuminating. Merleau-Ponty is commenting on the experience of the water in a pool. In a physical sense, the water is in the pool, but we may experience it differently when the reflections of the water reach to the top of the trees, and we may rather then experience the water in the space around us (Merleau-Ponty, 1964, 2002, p. 70ff.). Although Merleau-Ponty's specific concern is to understand the artist's perception and its relation to the material of painting, his overall interest is to discuss how an artistic interpretation of the world is a true perspective that supplements the scientific. Scientific thought is characterised as being at a distance to the world - in the words of Merleau-Ponty science is overflowing [survole] the world (p. 12; cf. Cassirer, 1932, 1998, p. 463).

The phenomenological interest is not simply in describing phenomena and different forms of perceiving; it is to give account of our perception, how it takes the form it does, how this form is constituted, and how we interpret it and legitimise the content (Heidegger, 1927, 1986, § 7c). We should understand the characteristics of atmosphere given by Böhme in this context. When the presence of something becomes primarily an identification of it as an object, the other elements present like colour, sound, etc. are considered secondary to our understanding, like we have become accustomed to in the language of modern epistemology. But they are not for that matter absent in our perception or without influence. What is present is something that comes forth from the thing. Böhme introduces the notion of ecstasies (Böhme, 2001, p. 131ff.; Böhme, 1995, p. 155ff.; Rauh, 2012, p. 90ff.) understood in its Greek origin as something that goes forth. We say a thing has qualities, but we don't experience a relation between the thing and its properties; we experience e.g. the blueness of the bottle and not the bottle being blue (Böhme, 1993, p 121). A similar description of how we experience architecture can be found when von Meiss talks about the radiance of a sculpture or building which is " the field of influence of an object » defining the field around it (von Meiss, 1990, p. 93ff.). The sculpture is not simply located in the room but it can take possession of the room, and we may feel something emanating from it, something meeting us between the sculpture and us, and organising our perception of the room.

Böhme's characteristics of atmosphere all contribute to demonstrate the fundamental role of being sensorial and bodily affected in our perception (Böhme, 1995 \& 2001; Rauh, 2012, p. 87ff.). This is more than an addition to the cognitive content of our perception, it is constitutive for what we perceive and experience. It is to be aware of something present and what it does to us, as well as being aware of our own presence among people and things (Böhme, 2006, p. 105). Emphasising how the organisation of the environment exercises an influence on us, on our being present in the world (ibid.), is both to relate to 
aesthetics as sensorial cognition as well as to the education of our sensibility, thus an aesthetic education.

\section{Aesthetics}

21 When differentiating between elements in our perception, such as the object and the different qualities like colours, sounds, and smell, we learn to focus and ignore - focusing on the object first and ignoring the qualities to begin with. We see a ball and that it is red; the child may see red before the ball and will be taught that what is red is a ball. An exception to this is when we allow ourselves to be subject to sensuous impressions as can happen in moments of aesthetic pleasure. In these moments we shift from the dominating cognitive interest in the world to dwelling on things, seeing them in a different « light »; we can then experience them in their presence without going beyond this presence (Seel, 2000, p. 49ff.). This act of changing between different perspectives is possible in all situations although we tend to be selective in when we do it as it could potentially be problematic - we should not dwell too long on the change between the green, yellow and red at the traffic light - and not all situations are equally inviting; to use the example given by Martin Seel: it is easier in the concert hall and at the museum than in the supermarket or at the dentist (p. 64).

Aesthetics is often, though not at all exclusively, about this perspective of dwelling. The museum exemplifies an institution for presentation of objects without a functional or user oriented context beyond the presentation; as exhibited it has become an object of dwelling, an occasion for taking objects out of their daily context and allow us to view them differently. Aesthetic appreciation is here a widely used term, not least when it is stated that "appreciative experience [...] lies at the heart of the aesthetic" (Berleant, 2010, p. 92); and such an appreciation of an object like a chair comes from dwelling on form, proportion, and materials, rather than on how comfortable the chair is to sit in. This appreciative dwelling provides us with an extraordinary perspective on ordinary objects (Leddy, 2012).

23 Aesthetic appreciation is an enrichment of our perspective on ordinary activities and involvement with our surroundings by making us aware of qualities in them, but it also stays within a tradition of the aesthetic being a particular aspect of something, a sentiment or feeling caused by a specific willed perspective on our environment. The concept of atmosphere opposes this tendency towards, what Hans-Georg Gadamer calls, aesthetic differentiation (Gadamer, 1960, 1990, p. 91). Gadamer emphasises how the separation of the aesthetic product from a broader context, which accompanies the idea of art and aesthetics since Romanticism, is also a loss of context, or a loss of a world to which the product belongs, due to the Romantic idea that the work of art is not fully of this world but one that creates a world (Gadamer, 1986, p. 7). This liberation of the aesthetic product from the culture and society that it originates in, is also a complication of its impact on the same context from which is has become separated. Sharing this concern about separation with Gadamer, the notion of atmosphere offers a reintegration into the world through awareness of how we are already sensorially and bodily integrated with our surroundings. Parallel to this is Gadamer's introduction of the concept of play, which exemplifies how we perform in ways congenial to different acts (p. 22ff.); we participate in the social reality by sensing and bodily performing acts based on norms we 
have exercised over time, and take as embodied knowledge. The social and cultural game we play is based on our participation, and thus recognition of the rules of the game.

There are limits to the parallels between atmosphere and Gadamer's hermeneutic interests, but both draw attention to how we should acknowledge aesthetic products as integrated into our world and not separated by standards set by an idea of aesthetics as only concerned with art and beauty. The new aesthetics, as Böhme calls it (Böhme, 1993), is concerned with a perspective on cultural products and, furthermore, with how these products communicate through different sensuous and bodily means. Such a perspective on aesthetics is strictly speaking not new but indebted to A.G. Baumgarten (Shusterman, 2000 , p. 262ff.; Böhme, 2001, p. 11ff.). It is aesthetics as sensorial cognition, the lower faculties of knowledge in the tradition of Leibniz and Baumgarten, to which we count social sense, common sense or faculty of judgement (Friberg, 2011; Shusterman, 2012, p. 129).

\section{Aesthetic Education}

Coming back to the suggestion of a fruitful intersection between atmosphere and aesthetic education, more is still to be said about how aesthetic education is understood.

One fundamental aspect of how we learn to manage everyday situations is through forming our sensorial and bodily ability to practice these situations. This forming is related to learning how we should exercise the different tasks of our lives in the most appropriate way. It is related to the characterisation of the orator by Quintilian, vir bonus dicendi peritus, the good man skilled in the art of speaking, (Quintilian, Institutio Oratoria, $12,1)$, the good man being the man who knows how to exercise his role as a citizen, a formula we find repeated again in, for example, il bel parlare and forming the background for the definition of aesthetics by Baumgarten when he includes ars pulchre cogitani, the art of thinking beautifully (Gadamer, 1986, p. 17). The ideals and directions of our behaviour serve as ideals for ordinary practices; ultimately, beautiful ways of talking and appearance is a matter of how we greet another person, walk through the restaurant, dine and make conversation and similar social practices. Training our practices of everyday situations is a fundamental aspect of our education for life, one we cannot acquire through books and codes of conduct based on abstractions and intellectual efforts; this is something we have to learn through participating in practices and exercising them ourselves. We learn through practice, and this practice forms us and determines how we do things.

In the most elementary form we recognise this from how as children we were influenced by what was around us, and how we imitated it. We became socialised into a community through such imitation which is not randomly left for children's playing but organized and given an intended content through the institutions of education. When, at school, we learned to sit quietly on a chair while listening to the teacher and doing assignments, it was not only a matter of keeping order in the classroom but also related to an idea of separating bodily activities from the mind at work and about discipline and hierarchy. The introduction here of aesthetic education is exactly in order to focus on the sensorial and bodily aspect of this.

It is for this purpose that music and dance have been used in classical education. Both Plato and Aristotle paid attention to how important music and dance were as educational 
activities due to their effect on citizens who were not merely spectators but participating themselves in the choir (Nietzsche, 1871, 1987, p. 67ff.). Through participating one learns to feel as if in real situations and thus also learns how the appropriate feeling in real situations should be (Plato, Laws II ; Aristotle, Politics VIII, 5). Dance, music, plays, and other art forms did not serve as objects of pleasure and contemplation alone but also, as said about theatre, to

strengthen the national character, to augment the natural inclinations, and to give

a new energy to all the passions (Rousseau, 1758, 1967, p. 71, my translation).

Of course being a spectator to a play implies an element of emotional involvement Aristotle's characteristics of peripeti and anagnorisis in the tragedy capture this (Poetics 11). What must be noted, however, is how it was also considered to have a communicative and educational purpose through the emotions (Sennett, 1977, 1992, p. 35ff.) something no less present in more recent forms of theatre when, for example, the Brechtean alienation effect is also meant to have an impact on us through an emotional and intellectual inclusion (Brecht, 2008, p. 91).

These examples coming from theatre draw attention to how aesthetic products of all kinds, not only within the arts, have been understood to be of importance for affecting us. Combined with Gadamer's concept of play above, it is emphasised how our involvement in social matters is based on a sensorial and bodily interaction with our environment. Play underlines how we learn by imitation and practise; we will not become good players by thoroughly studying a set of rules, only by using them - only through practice. This aspect does not have a prominent place in contemporary aesthetic discourses, whether they are about theatre, music, dance, painting or other art forms, where the interest is more often on interpretation or an aesthetic experience, appreciation or similar responses to the aesthetic situation. It is rather to be found in debates on products of popular culture where concern is raised as to their problematic influence on the consumers, whether violent artefacts may lead to violent acts or the products of cultural industries support a particular form of society filling empty time with emptiness (Adorno, 1970, 1989, p 365) reproducing the empirical reality without any critical distance (p. 336).

An echo of Adorno's critique can be found in the Situationist critique of Modernist architecture where ideals of forming modern, rational, people through modern and rational planned architecture (Le Corbusier, 1923, 2002) is criticised for being a tool for a modern, capitalist society (Berréby, 2004). We find here an example of a debate on the effect of the organisation of the environment on us, where intentions of influencing and educating through the material organisation are made explicit. Studies of this will belong to studies in material culture and psychology while the intention here has been to bring it within the interest of aesthetics to emphasise how atmosphere concerns the elements of our perception that influences our understanding of and responses to the environment which in return makes the forming of them by the environment crucial.

The characteristics of our perception given by Böhme, such as physiognomy and ecstasies, contribute to make us aware of how perception is more than an identification of something as something (Böhme, 1995, p. 101ff.; Böhme, 2001, p. 101ff. and 131ff.). According to the dominant description of perception I see the bottle that is blue, not the blueness, or I experience the space of the railway station which is full of busy people creating an intensity of movements and noise rather than experiencing the hectic atmosphere which is enclosed in a specific room. Or, is that what we see and experience? Are the bottle and the railway station first and colour and activities second? Or is the 
order of first and second in perception a product of a specific approach needed for orienting ourselves and communicating with others but also making us less aware of the importance of the other elements?

When walking through the hectic atmosphere no doubt the orientation among people and objects is fundamental, one can just think of the little child who gets lost when there are no familiar fix-points to orient from. But walking through we do more than orient ourselves, we also respond to the place and people - to the organisation of the space guiding us through as well as to many small components of our social interaction. Returning to the example of Merleau-Ponty with the water in the pool we perceive the space enclosing the water not as a neutral space where water is located but as a tuned space also tuning us. We experience this when we find ourselves in a place that is foreign to us, and we feel uncomfortable that we cannot tune into the place - where our pretunement, to make a parallel to the pre-understanding of Gadamer (1960, 1990, p. 272ff.), fails us and we seek to understand the situation like we struggle with understanding a text. We can make an experience and learn new but we should also take it as an opportunity to become aware of our prejudices where we may become aware of how we already embody a particular ideology, perhaps of how we bodily approach and respond to the opposite sex or a superior at our workplace (Shusterman, 2012, p. 32).

The presence of the other person makes us respond because we have learned and appropriated this type of response to someone or something. When we become aware of our acts, or the responses to our acts that we encounter, we may also try to explain them. Like the dancer's experience of the audience's impatient response to stillness in dance where the expectation is progression in movements is also to feed their own confirmation of following and consuming the idea:

I see you are digging a hole in the ground, I get it. Now what's next? Where is it going? What does it mean? (Tiusainen, 2010, p. 150).

The response is more than the audience's expectation or an aesthetic criticism, it can be seen as a response to the challenge of a consumer culture with its permanent requirement for change, speed and innovation which we embody (p. 148ff.). Likewise we embody social positions and roles (Shusterman, 2012, p. 98), and these have their material appearance in the environment, in how objects and buildings exercise a direct influence on us, organising the space around us, and through that influencing patterns of movement and creating space for different activities. The environment contributes to the formation and training of our sensibility through sensuous elements. It is in relation to this that aesthetic education should be taken as an awareness and forming of our sensorial and bodily habits and our sense of situations and other people.

We practice this training to become socialised into the different communities we belong to, but to a large degree we are not aware of how and what we do as we have appropriated and embodied this training. We do not think of how to exercise most daily acts, we simply act. Becoming aware of our sensorial and bodily training as well as how it materialises in our environment is what the concept of atmosphere contributes to. But because our socialisation is embodied and exercised through our daily practices it not only requires an intellectual effort to discover the different elements to analyse and interpret them, but we also should be asked to train our awareness, as well as to train our use of sensibility and bodily awareness. In a philosophical context this has been pointed out by Richard Shusterman in his suggestion of a practical somaesthetics, introducing 
somaesthetics as a combination of soma and aesthetics (Shusterman, 2000, p. 262ff.) where the practical somaesthetics

is not a matter of producing theories and texts [...] It is instead all about actually practicing such care through intelligently disciplined body work aimed at somatic self-improvement (p. 276)

I may become aware of how I exercise certain bodily postures that embody a relation of power with my students - perhaps I even have different appearances with a more open and welcoming attitude to some and not to others. We embody many such roles and change between them, or bring them with us unaware (Shusterman, 2012, p. 66 and 107ff.); roles learned while learning the social game we participate in and forming our ethical character (Böhme, 2003, p. 82; Shusterman, 2012, p. 32). Forming our ethical character through sensorial and bodily exercises is the task for the aesthetic education, and becoming aware of the sensorial and bodily elements in our environment is the task of aesthetics guided by a focus on atmosphere. Together, atmosphere and aesthetic education form a potent critical reflection on the implications of the forming of our environment, as this forming is a forming of our perception thus of our understanding of the world.

\section{BIBLIOGRAPHY}

Adorno, Theodor W. 1989 [1970]. Ästhetische Theorie. Frankfurt am Main: Surhkamp.

Berleant, Arnold. 2010. Sensibility and Sense. The Aesthetic Transformation of the Human World. Charlottesville: Imprint Academic.

Berréby, Gérard (ed.). 2004. Textes et documents situationnistes, 1957-1960. Paris: Éditions Allia.

Böhme, Gernot. 1993. Atmosphere as the Fundamental Concept of a New Aesthetics. Thesis Eleven. $\mathrm{n}^{\circ} 36$, p. 113-126.

Böhme, Gernot. 1995. Atmosphäre. Essays zur neuen Ästhetik. Frankfurt am Main: Suhrkamp.

Böhme, Gernot. 2001. Aisthetik. Vorlesungen über Ästhetik als allgemeine Wahrnehmungslehre. München: Wilhelm Fink Verlag.

Böhme, Gernot. 2003. Leibsein als Aufgabe. Leibphilosophie in pragmatischer Hinsicht. Kusterdingen: Die Graue Edition.

Böhme, Gernot. 2006. Architektur und Atmosphäre. München: Wilhelm Fink Verlag.

Brecht, Bertolt. 2008. The Street Scene. A Basic Model for an Epic Theatre. In: Bentley, Eric (ed.). The Theory of the Modern Stage. From Artaud to Zola: An Introduction to Modern Theatre and Drama. London: Penguin. p. 85-96.

Cassirer, Ernst. 1998 [1932]. Die Philosophie der Aufklärung. Hamburg: Felix Meiner Verlag.

Chesterfield, Philip D. S. Lord. 2008. Letters. Oxford: Oxford University Press.

Di Stefano, Elisabetta. 2012. Iperestetica. Arte, natura, vita quotidiana e nuove tecnologie. Palermo:

Centro Internazionale Studi de Estetica. 
Friberg, Carsten. 2011. Contemporary Culture and Aesthetic Education. Proceedings of the European Society for Aesthetics. vol. 3, p. 104-114.

Gadamer, Hans-Georg. 1986. The Relevance of the Beautiful. Art as Play, Symbol, and Festival. In: Ibid. The Relevance of the Beautiful and other Essays. Cambridge: Cambridge University Press. p. 3-53.

Gadamer, Hans-Georg. 1990 [1960]. Wahrheit und Methode. Grundzüge einer philosophischen Hermeneutik. Tübingen: J.C.B. Mohr.

Griffero, Tonino. 2010. Atmosferologia. Estetica degli spazi emozionali. Rom: Editori Laterza. Gross, Julius. 1960. Entstehungsgeschichte des Erbsündendogmas. Von der Bibel bis Augustinus. München/Basel: Ernst Reinhardt Verlag.

Gross, Steffan W. 2002. The Neglected Programme of Aesthetics. British Journal of Aesthetics. vol. $42, \mathrm{n}^{\circ} 4$, p. $403-414$.

Hegel, Georg W.F. 1999 [1970]. Vorlesungen über die Ästhetik I. Frankfurt am Main: Suhrkamp. Heidegger, Martin. 1986 [1927]. Sein und Zeit. Tübingen: Max Niemeyer.

Laporte, Dominique. 1993 [1978]. History of Shit. Cambridge, Mass. and London: MIT Press.

Le Corbusier, Charles-Edouard J. 2002 [1923]. Vers une architecture. Paris: Flammarion

Leddy, Thomas. 2012. The Extraordinary in the Ordinary. The Aesthetics of Every Day Life.

Peterborough: Broadview Press.

Maldonado, Tomas. 2000. The Idea of Comfort. In: Margolin Victor, Buchanan Richard (eds.). The Idea of Design. Cambridge, Mass. and London: MIT Press. p. 248-256.

von Meiss, Pierre. 1990. Elements of Architecture. From Form to Place. London: Van Nostrand Reinhold.

Merleau-Ponty, Maurice. 2002 [1964]. L'œil et l'esprit. Paris: Gallimard.

Nietzsche, Friedrich. 1987 [1871]. Die Geburt der Tragödie aus dem Geiste der Musik. Frankfurt am Main: Insel Verlag.

Perniola, Mario. 1997. L'estetica del Novecento. Bologna: Il Mulino.

Rauh, Andreas. 2012. Die besondere Atmosphäre. Ästhetische Feldforschungen. Bielefeld: Transcript Verlag.

Rousseau, Jean-Jacques. 1967 [1758]. Lettre à d'Alembert. Paris: Flammarion.

Scheer, Brigitte. 1997. Einführung in die philosophische Ästhetik. Darmstadt: Primus Verlag. Seel, Martin. 2000. Ästhetik des Erscheinens. München: Carl Hanser.

Sennett, Richard. 1992 [1977]. The Fall of Public Man. New York, London: W.W. Norton \& Company. Shusterman, Richard. 2000. Pragmatist Aesthetics. Living Beauty, Rethinking Art. Lanham: Rowman \& Littlefireld Publishers, Inc.

Shusterman, Richard. 2012. Thinking through the Body. Essays in Somaesthetics. Cambridge: Cambridge University Press.

Thibaud, Jean-Paul. 2003. Die sinnliche Umwelt von Städten. Zum Verständnis urbaner Atmosphären. In : Hauskeller, Michael (ed.). Die Kunst der Wahrnehmung. Beiträge zu einer Philosophie der sinnlichen Erkenntnis. Kusterdingen: Die Graue Edition. p. 280-297. 
Tiusainen, Larissa. 2010. Being Present - Meditation in Movements. In: Friberg, Carsten; ParekhGaihede, Rose \& Barton, Bruce (eds.). At the Intersection Between Art and Research. Practice-Based Research in the Performing Arts. Malmö: NSU Press. p. 145-164.

Toulmin, Stephen. 2003. Return to Reason. Harvard: Harvard University Press.

zur Lippe, Rudolph. 2000. Sinnenbewusstsein. Grundlegung einer anthropologischen Ästhetik I-II. Baltmannsweiler: Schneider-Verlag Hohengehren.

\section{ABSTRACTS}

In this article the coupling of atmosphere and aesthetic education is proposed as an intersection between awareness of the sensorial and bodily aspects of our everyday practices such and the training of our sensibility towards such sensorial and bodily awareness in specific situations. The concept of atmosphere is introduced to create awareness of how sensorial aspects affect us, and also to explore how perception is about the presence of something. Atmosphere is also a primary concept in aesthetics and relate to a classical tradition of education through sensorial and bodily products. Through a presentation of atmosphere and aesthetic education the intersection between them is suggested as a field for further investigation and also additional training.

Dans cet article, la combinaison de l'ambiance et de l'éducation esthétique est proposée comme un croisement entre les aspects sensoriels et corporels de nos pratiques quotidiennes, telles que l'entrainement de notre sensibilité face à des situations spécifiques à travers l'attention sensorielle et corporelle. La notion d'ambiances est introduite à la fois pour rendre intelligible la façon dont les aspects sensoriels nous affectent, et pour investir le concept de perception, qui traduit la présence de quelque chose. L'ambiance est aussi un concept primordial dans l'esthétique, où elle a trait à toute une tradition de conception de l'éducation au travers de productions sensorielles et corporelles. Par une présentation de l'ambiance et de l'éducation esthétique, l'intersection entre elles est proposée comme un champ de recherche comme de pratiques à approfondir.

\section{INDEX}

Keywords: atmosphere, aesthetics, education, philosophy, affecting, sensorial

Mots-clés: ambiances, esthétique, éducation, philosophie, affectant, sensoriel

\section{AUTHOR}

\section{CARSTEN FRIBERG}

$\mathrm{PhD}$ (philosophy), Independent researcher, Istedgade 61, 3.tv., 1650 København V, Denmark e-mail: carstenfriberg@gmail.com 